\title{
An open-source framework for publishing geographical names - A case study of Kenya
}

\author{
Daniel NYANGWESO - Mátyás GEDE
}

DOI: $10.30921 / G K .73 .2021 .2 .4$

Absztrakt: Az önkéntes földrajzi adatok (volunteered geographic information, VGI) mára egy jelentốs eröforrássá váltak, amelyek szabadon elérhetôk a világhálón. Közösségi alapú projektként óriási az alkalmazási potenciáljuk a földrajzinév-tárak fejlesztésében, alkalmazásukkal kis költséggel lehet akár a hivatalos nemzeti térképmúveket is naprakészen tartani. Jelen cikk célja egy nyílt forráskódú keretrendszer segítségével fejlesztett digitális földrajzinévtárszolgáltatás bemutatása, amelyet egy webes és mobilalkalmazás támogat. A szerzók létrehoztak egy, a Django keretrendszeren alapuló szolgáltatást, mely egy PostgreSQL adatbázisban tárolja az összegyújtött adatokat. A webes és a mobilalkalmazás összekapcsolása az adatbázissal, a gyüjtött adatok feltöltése egy REST végponton keresztül valósul meg. A földrajzinévtár-szolgáltatás különféle térképi vizualizációs eszközöket kínál a helynevek és a köztük lévó kapcsolatok bemutatására a szöveges korpusz alapján. A szolgáltatás testre szabható bármely földrajzi területen történô használatra a konfiguráció megfeleló beállításával, és az engedélyezett adatmennyiség és a szolgáltatási hitelesítôk számkorlátozásának feloldásával, beleértve a funkcionalitás növelését. A névtár-keretrendszer tesztpéldányát az elérhetố kenyai földrajzi nevekkel feltöltve és tesztelve az eredmények és a rendszer teljesítménye átlagon felüli eredményeket mutatnak a névtár-bejegyzések frissítése, az információk térképi megjelenítése és földrajzinév-örökség megốrzésének területén. A Django API keretrendszer összes kódfájlja és kódkonfigurációja elérhetố az Atlassian online tárhelyen.

Abstract: Volunteer data has the potential to update gazetteers and topographic maps at minimal cost after authentication. This paper proposes using a toponym gazetteer service for updating records stored in a PostgreSQL database by using Django, an open-source framework with the integration of web and mobile applications. The toponyms gazetteer service includes embedded visualization tools for performing place name relations using a text corpus and geoparsing. The gazetteer service is customizable for use in any area by modifying the URL of storing data collected and removing the limitation of the number of authorized data and service authenticators, including increasing its functionalities. The code implementation was in Python and storage in Atlassian. The test results application in Kenya and some parts of the world by volunteers gave above-average results in updating gazetteer records, visualizing mapped features in its repository, and enriching geographical names' heritage records.

Kulcsszavak: földrajzinév-tár, GeoNames, névrajz, önkéntes adatszolgáltatás Keywords: gazetteer, GeoNames, toponym, Volunteered Geographic Information (VGI)

\section{Introduction}

Gazetteers describe toponyms locations about a name, type (Acheson et al. 2017; Hill 2000; Keßler et al. 2009) and associated attributes about objects represented and sometimes the content linked using toponyms ontologies (Hećimović-Ciceli 2013), which makes them referred to as toponym ontologies some of which are in DBpedia archives ${ }^{1}$. There are persisting issues in gazetteers such as identifying related places of the same name and how to use gazetteers in multilingual, diverse areas with enhanced content (Knowles 2018) in addition to searching and geocoding. Gazetteers traditionally support queries for the presence or absence of place names

1 https://archivo.dbpedia.org/ in a map with documentation on changes or history. In general, they are a vocabulary of toponyms expressing the human factors in naming places (Meiring 2008) in a historical culture passed from generation to generation. Different types of gazetteers exist such as simple (which consist of a list of place names), index (which has a map in addition to a list), addressing (containing postal code addresses), hydrology (for toponyms of hydrographic features like lakes, rivers, streams, seas, and oceans) (Laurini 2015). Furthermore, there are cadastral ones with land records such as the OpenELS ${ }^{2}$ or National Land and Property Gazetteer ${ }^{3}$.

\footnotetext{
2 https://openels.eu/

3 https://data.gov.uk/dataset/9231ef97-a965 4d91-97c4-482d33de459a/national-landand-property-gazetteer
}

The linked gazetteers can also maintain relations in the administration of boundaries for different dialects (Laurini 2015). Semantic-based gazetteers are digital, and examples range from worldwide coverage such as Thesauri's, GeoNames, The Pleiades, and World-Historical Gazetteer (WHG) and digital gazetteers all available on the web by individual countries. Some states have resorted to incorporating Volunteered Geographic Information (VGI) to reduce cost by supplementing the traditional methods using VGI data in updating gazetteer records. Significant applications of VGI include photo interpretation, change detection, report alerts, new data collection for unmapped areas, and vernacular place names 
(Olteanu-Raimond et al. 2017). Maintaining updated gazetteers of geographical names is expensive. It has necessitated National Mapping Agencies (NMA) to adopt sustainable opportunities to keep the records up to date through the use of VGI data collection strategies (Felgenhauer 2018; Knowles 2018; Oliveira et al. 2016; Olteanu-Raimond et al. 2017; Perdana-Ostermann 2018; Smart et al. 2011). For this reason, most gazetteers, especially for the third world and developing countries, do not have updated gazetteers for the enhanced discovery of feature semantics (Machado 2017) through the use of a linked-open data cloud due to its broad access. Such examples of Linked gazetteer concepts include Onto Gazetteer (Smart et al. 2011) and spatial relationships (Machado et al. 2011). Toponym disambiguation helps to assign unique identities to places. It includes using topological relations, proximal distances, and arborescent relationships (Bensalem-Kholladi, 2010) using natural language processing techniques or GIS applications.

The lack of internet access is one of the impeding factors derailing the full realization of VGI data's potential in locations outside the urban setups. Consequently, there are empty un-mapped areas on web maps, and topo maps have open spaces without features worthy for mapping since there are few Twitter users or the internet in rural set-ups. Besides, most recent and new research appears to concentrate on collecting or using VGI data in urban centres and intentionally ignoring the rural areas. There are challenges in either getting VGI data or collecting it in rural set-ups. This paper aims to develop a prototype gazetteer service accessible in mobile and web interface using simple open-source tools to document and visualize toponym records in a gazetteer service. The toponyms gazetteer development involves applying OpenStreetMap (OSM), Leaflet, and PostgreSQL alongside Python and Nginx web server.

\section{Related works}

\section{The power of VGI data in gazetteer development and update}

User-contributed data research for enriching gazetteers is a widely researched area with diverse OSM data approaches (Haklay-Weber, 2008). The quality evaluation of OSM data (Basiri et al. 2016; Haklay 2010), contributed by 7.5 million registered users who have so far generated 6.5 billion features entities ${ }^{4}$, reveals it has great potential. There are various semantic relations of the data (Ballatore et al. 2012; Machado et al. 2011). The incorporation of OSM and GeoNames data by most researchers, developers, and corporations (Smart et al. 2011), informed and motivated the research due to its wide acceptance as the most trusted spatial resource. Geoparsing is defined as a method of extracting coordinates and names identified by the coordinates, unambiguously by toponym resolution process or geoparsing. VGI data application ranges from geoparsing, especially for GeoNames data, and OSM as a background base map in most free web maps. GeoNames data in enriching or validating our database is most geoparser data used in most Geographic Information Retrieval (GIR) systems such as Stanford ${ }^{5}$, Edinburgh $^{6}$, and Apache ${ }^{7}$, since due to its advanced linked open data cloud and has worldwide coverage. The Map Gretel project (Rönneberg et al. 2018) uses detections by residents of Finland map errors.

Besides Twitter data (Klaus 2020), urban VGI data has been applied to detect user activities in the Twitter text, such as one-million tweet map ${ }^{8}$ and with also a strategy for one-billion tweet map (Jia et al. 2017). Rationally data has been mined for gazetteer enrichment using VGI (Inkpen et al. 2017; Klaus 2020; Oliveira et al. 2016).

\footnotetext{
${ }^{4}$ https://www.openstreetmap.org/stats/data stats.html

$5 \underline{\text { http://nlp.stanford.edu/software/CRF-NER }}$ shtml

$6 \underline{\mathrm{https}: / / w w w . l t g . e d . a c . u k / s o f t w a r e / g e o p a r s e r} /$

7 http://opennlp.apache.org/

8 https://onemilliontweetmap.com/
}

Some use location-based service while others use basic user-contributed information with no processing needed, such as fix-mystreet ${ }^{9}$ (Walravens 2013), which involved residents providing information on streets with issues that require city managers' attention. Most gazetteers rely on VGI data to interact with linked open data (Cardoso et al. 2015). Cardoso's evaluation of existing gazetteers noted that the gazetteers could not undertake complex queries and perform spatial relations. Our approach has an improved toolset to counter the issues indicated in most gazetteers, such as the use of mobile generated data configured to generate data as per the gazetteer schema standard in addition to performing geoparsing and relation characterization. If that data does not originate at the rural level, since most cluster at the urban centre, the gazetteer will have missing linked data. In all the cases mentioned earlier, research concentrated majorly in urban areas due to data availability while excluding the rural areas where most VGI users do not contribute data. Our methodology focuses on using contributed data and formal geospatial data for rural areas in a simple way through a web application or a mobile app. Each coordinate triple has a link to identify it spatially. This methodology involves using open-source technologies such as Leaflet, Bootstrap, Bootleaf, ontology web languages, API frameworks and geoparsers in the gazetteer framework. Geographic datasets incorporated in the prototype gazetteer development include GeoNames and DIVA-GIS. Validation of the source's datasets involved using administrative data to improve some VGI sources' data quality.

\section{Heritage of related places in Kenya and Hungary}

A text corpus of the related place was populated and integrated within the gazetteer service in the gazetteer for use in toponym disambiguation using lines connecting related areas with

9 https://www.fixmystreet.com/ 
their locations. It contains place names of various typologies, both in Kenya in several places and other parts of the world, for commemorating those names of people who hold significance and fame. Count Teleki is one of the legendary Hungarian scholars and is also a name of a volcano in Kenya. Teleki's name is still used in topo maps due to mapping most of East Africa and named a nearby lake after Rudolf of the Austria-Hungary Empire. Currently, only the Teleki volcano holds, while that of Rudolf, as a toponym erased in favour of Lake Turkana.

\section{Methodology}

The design of the

\section{toponym gazetteer}

The methodology involves developing a framework for updating and enriching gazetteers in rural environments by applying an offline application, enabling place names and heritage data collection for areas with no internet access, with or without a web mapping application, cost-effectively. The approach also uses a customized Django web framework (HolovatyKaplan-Moss 2008), an open-source tool for gazetteer website building, authentication, and administration. The framework uses Python and JavaScript Object Notation (JSON) as the primary data format used in the gazetteer and Nginx as a server. Additionally, toolsets such as data exporter, geoparser, and related integrated places with a visualized web map in the WGS84 coordinate system with open-source tile servers.

Firstly, Django framework installation and configuration completed running locally before porting it to a web server. We also created an endpoint to hook data from a toponym's mobile app to a PostgreSQL data storage point for visualization in a Leaflet webmapping platform. An endpoint is like a Universal Resource Locator (URL) that allows the Django API framework to access resources on a server. All code scripts and the configured code from the Django API framework are stored in Atlassian, an online backup platform. The main products include a gazetteer service in addition to visualization tools. System testing done reveals users had access to and interaction with the system from all over the world as per the analytics generated and, so far, no flaws or communication breaks on data payloads.

\section{Study area}

The study area is Kenya and is in East Africa, with about 47 million people per the 2019 KNBS census. According to world population statistics ${ }^{10}$, the 2020 estimated population of Kenya is 53.8 million.

\section{Toponym Gazetteer framework}

The toponyms gazetteer shown in Fig. 1 has an embedded repository of base map layers with Leaflet tile layers. It includes historical data from authoritative gazetteer data (AGI), volunteered records from the web mapping application users, toponyms app, and initial data imported to PostgreSQL during database set-up, maintenance, and update. Furthermore, toponyms gazetteer integrates embedded tools such as visualization of toponyms ontology, searching a place name, a geoparsing, and picking sub-location boundaries during editing of gazetteer content. The entry, editing, and visualization of data validation are through

\footnotetext{
10 https://worldpopulationreview.com/
} countries/kenya-population

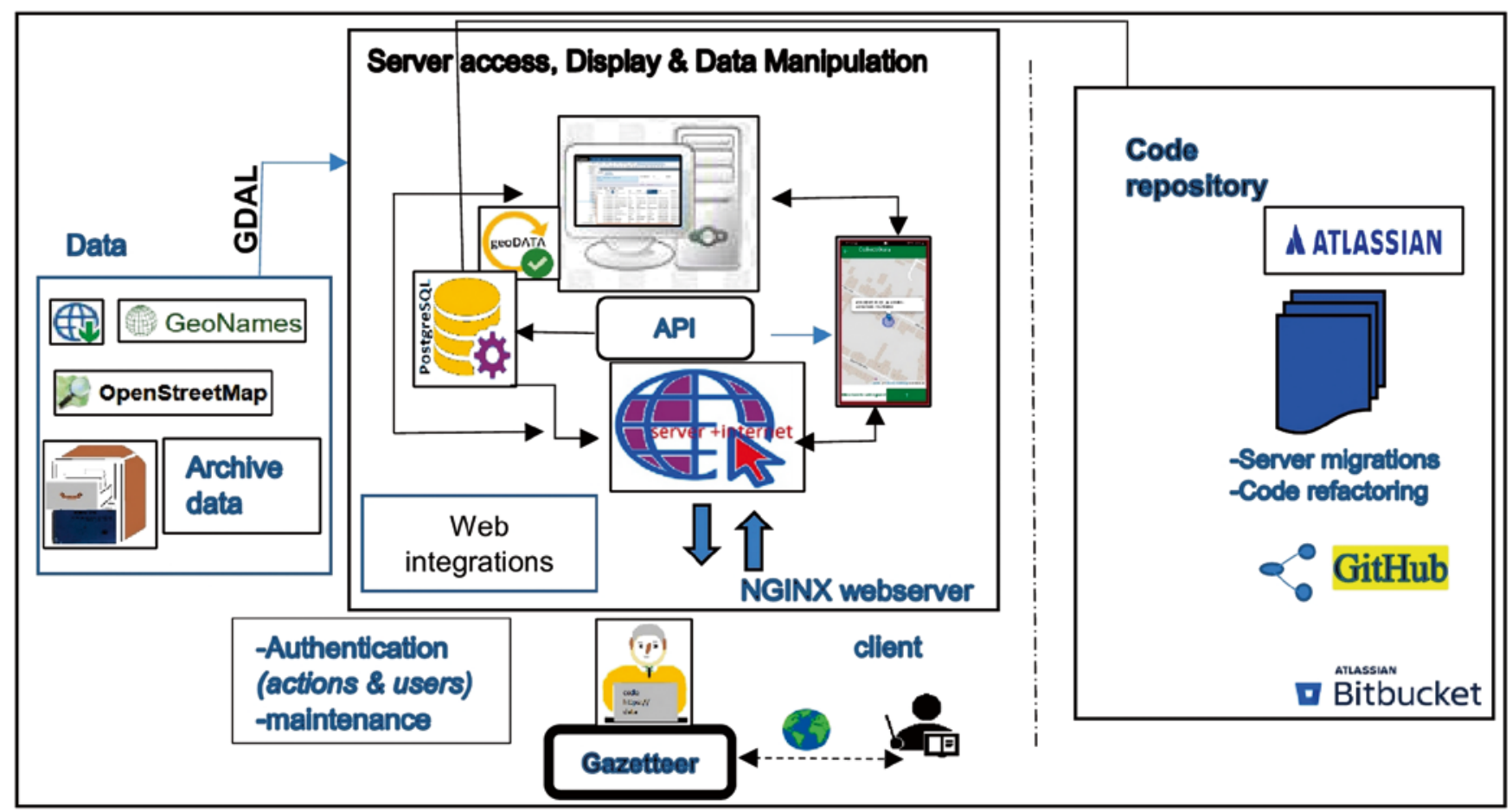

Fig. 1. Data integrations. The data integrations include downloading GeoNames database dump, archive gazetteer, combining data from hooking data collected by app to PostgreSQL database. When all workflows for new data collection synchronization have been streamlined, the data can be processed and accessed publicly by the server and any web browser once authenticated. 
Table 1. Data sources and their uses

\begin{tabular}{|l|l|l|l|l|}
\hline & Data & Provider & Purpose & Source \\
\hline 1 & GeoNames & GeoNames & Enriching and authentication & $\underline{\text { http://www.geonames.org/datasources }}$ \\
\hline 2 & Gazetteer data & $\begin{array}{l}\text { United States Board on } \\
\text { Geographical Names }\end{array}$ & Fundamental data & 1962 Gazetteer data \\
\hline 3 & AGI & Kenya Open Data portal & Authentication & $\underline{\text { http://www.opendata.go.ke/ }}$ \\
\hline 4 & OSM & OSM (OpenStreetMap) & Web map & $\underline{\text { https://www.geofabrik.de/data/ }}$ \\
\hline
\end{tabular}

Table 2. Tools for place name relations

\begin{tabular}{|l|l|}
\hline Tool & Function \\
\hline PostgreSQL/Postgis & Database for storing and viewing spatial data \\
\hline Python & The programming language used in system development \\
\hline GEOS/GDAL & Library for spatial data manipulation \\
\hline Django API & The framework used to develop the web application \\
\hline Django REST API & $\begin{array}{l}\text { An implementation of Django that enables the use of API } \\
\text { endpoints for communication between web service and mo- } \\
\text { bile application }\end{array}$ \\
\hline GIT & Code versioning system to track changes within the codebase \\
\hline JavaScript & Toponyms system-web application run-time \\
\hline Nginx & User interface server application \\
\hline
\end{tabular}

signing in to an admin interface for toponym relation and web-based visualizations.

Table 1 contains spatial data used in the toponym's framework design, while Table 2 indicates the tools used to manipulate data and the development of the open-source framework.

\section{Database matching and comparisons}

Spatial and graphical data matching techniques helped compare the number of data records in the AGI matching with VGI repositories. Matching current AGI records with 31,172 GeoNames data and OSM showed that 17,266 (64.9\%) GeoNames records matched those in AGI, while 9,334 (35\%) did not match the 26,600 in the AGI database.

Besides, there is a provision for reading records about added place names, prototype gazetteers, and GeoNames gazetteers. Each of these lists of names has its URL link pointing to its spatial location and the feature described in the respective database for each query accompanied with a web map visualization.

One can search any toponym in the OSM database worldwide using the search tool provided on the toponyms service map area. The gazetteer offers free access to visualizing related places, geoparsing and a web ontology in OWL (Web Ontology Language) visualized using WebVOWL online ontology viewing web application. The ontology enables one to view all the contents of the gazetteer and its metadata.

The toponyms site's administration is through a "Sign in" to Toponym admin site for registered users. The toponym, a Django framework, is an open-source tool that connects with the PostgreSQL database, which provides hosting of all the web resources and resulting data generated from users. There is also a brief guide on the website on how to make the best of the website.

Lastly, a website search tool enables access, discovery, and web visualization of any name in any of the three browsed records of added place names, prototype gazetteers, and GeoNames. Additionally, related

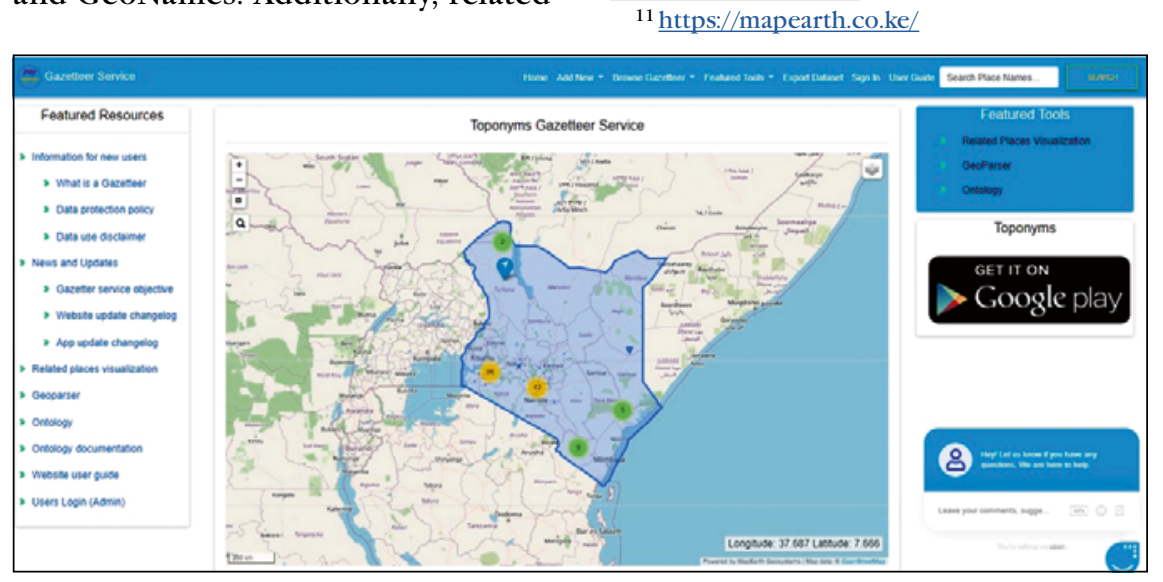

Fig. 2. Toponyms gazetteer. The gazetteer interface shows the GUI of the features resources, web map visualization of the various place names found in the database records of added place names, Prototype gazetteer, and GeoNames gazetteer records. places visualized via the related-place toolset, linguistically connected but physically separated, whereby intensive reasons for how the names are related are beyond this project's scope.

\section{Results and Discussions}

\section{Toponym gazetteer service Graphic user interface (GUI)}

The toponyms interface shown in Fig. 2 contains four usable resources in the top navigation bar, whereby each has its capability. It is available online at https://mapearth.co.ke/11

The navigation bar enables one to add a new place name to the gazetteer, browse gazetteer contents, access featured tools, export free data, sign in and search toponyms. One can also add either a place name, card record, or a related place name using provided forms based on details available via the web map application or using the android toponyms app from the Google play store.

\section{Validation of data for public access}

Once data arrives at the toponyms central database, it passes through verification and checks for its

\section{${ }^{11}$ https://mapearth.co.ke/}


authentication and approval for display in the toponyms gazetteer as shown in Fig. 3. Usually, Django provides the web framework free up to five users for non-profit projects, but some fee is required if one requires more resources. Verification of the prototype data overlays GeoNames and prototype data over OSM, satellite image layer, newly added place names, and open topo map, outdoor and street tile layers interchangeable based on selected base map for close validation matching. We chose the GeoNames and the image layers since they are free and have dense data. Names which did not appear in GeoNames or not on any newly collected data of AGI qualified for expunging.

Based on these overlays, we verified 5,401 records from selected five counties from 47 counties, which have 26,600 records of AGI and 31,000 GeoNames records The administrative sub-locations data helped validate the bounds of toponyms aided by the sub-location picker tool hence aiding in the discovery and correction of displaced toponyms. The presence of old names in the GeoNames records, some booked as alternative names, helped in knowing changed or erased names, especially in multilingual areas and towns.

\section{Toponyms Gazetteer Service}

\section{Geographical Names Service}

\begin{tabular}{|c|c|c|c|}
\hline \multicolumn{3}{|c|}{ AUTHENTICATION AND AUTHORIZATION } & \multirow{2}{*}{ Recent actions } \\
\hline Groups & + Add & Change & \\
\hline Users & + Add & Change & My actions \\
\hline \multirow{2}{*}{\multicolumn{3}{|c|}{ GAZETIEER \& SUB-LOCATIONS }} & $\begin{array}{l}\text { Kipsigis/Lumbwa } \\
\text { Oustet }\end{array}$ \\
\hline & & & If Kipsigis/Lumbwa \\
\hline Card Record & + Add & Change & Divloct \\
\hline Prototype Gazetteer & + Add & Change & $\begin{array}{l}\text { Osumu } \\
\text { Topospm }\end{array}$ \\
\hline Sub-Location Boundaries & + Add & Change & takeran \\
\hline GAZETIEER LAYERS & & & $\begin{array}{l}\text { SOK short pillar } \\
\text { Toporym }\end{array}$ \\
\hline Added Place Names & + Add & Change & $\begin{array}{l}\text { SoK pillar } \\
\text { Tsporym }\end{array}$ \\
\hline Dialects/Languages & + Add & Change & Kiriaini \\
\hline Feature Classes & + Add & Change & Toposym \\
\hline Feature Historical Associations & + Add & Change & Toporym \\
\hline Sub Dialects/Sub Languages & + Add & Change & $\begin{array}{l}\text { glongong } \\
\text { Teposym }\end{array}$ \\
\hline Sub-Feature classes & + Add & Change & glongong \\
\hline \multicolumn{4}{|l|}{ GEONAMES GAZETTEER } \\
\hline GeoNames Gazetteer & + Add & Change & \\
\hline \multicolumn{3}{|l|}{ PLACE NAMES RELATIONSHIPS } & \\
\hline Cadinality & + Add & Change & \\
\hline Level of Relation & + Add & Change & \\
\hline Ralated Place Names & + Add & Change & \\
\hline Ralation Type & + Add & Change & \\
\hline Spatial Relation & + Add & Change & \\
\hline
\end{tabular}

Fig. 3. Administration site of the gazetteer 
The toponym data verification using an online questionnaire involved 438 respondents who checked and added about 450 new place names previously not in the gazetteer via the add new place name web application. All the records have unique URL for visualizing their geographic location to use different base map tiles for further checks and verification. Data compilation was in GeoNames web and was used for Gazetteer database validation, as shown in Fig. 3. There is a potential for the increased quality collection, update, and enrichment of the Prototype gazetteer record. However, drawbacks for these records include the GDAL library, which is not GeoSPARQL compliant with their editors $^{12}$. The administrative site of the gazetteer GUI is in Fig. 3.

Fig. 3 indicates the Toponyms gazetteer service authentication site. This site enables the registered users to edit data located in the PostgreSQL

\footnotetext{
${ }^{12}$ http://dbpedia.org/sparql,

http://lod.openlinksw.com/sparql,

http://linkeddata.uriburner.com/sparql, and $\underline{\text { http://kingsley.idehen.net/sparql }}$
}

database. All the gazetteer data layers can also be compared alongside the GeoNames data. On the interface there is monitoring of all edits to account for all actions effected on the database such as deletions, flagged with $\mathrm{X}$, while edits are bulleted with pen like marks in front of each action. Data posted into the databases passes through use case testing, production and historical records for validation on the site.

\section{Toponym Gazetteer Interface; app}

Fig. 4a shows the mobile app's home page, where a user picks what is required to be mapped on current location or away; with the option to show data added and exporting to device internal storage

Fig. $4 \mathrm{~b}$ indicates the GUI of adding a place name on the map, on and off toggling "my location" coordinates, while Fig. $4 \mathrm{c}$ shows the interface for adding toponyms to the toponyms database directly using the GPS icon and choosing the type of feature geometry to record the added point description. All the gazetteer entities listed in Fig. 3 are captured using either the app or the web application. Using the web application, one can select a point, line, or polygon feature to assign a name. Similarly, in the mobile app GUI, one can choose what kind of feature geometry to add to the database in addition to the associated attributes by clicking the satellite icon (found at feature coordinates tab) to define the added point(s) as either as a point data auto-located as a drop pin (point), draw polygon, or line feature as well as show current location of the device collecting.

\section{Conclusion}

In the Toponyms gazetteer, we presented a prototype framework that uses open-source web tools and VGI data to link toponyms to geographic footprints. The views of UNGEGN on the use of common feature types, supported by records, were reviewed based on Alexandria

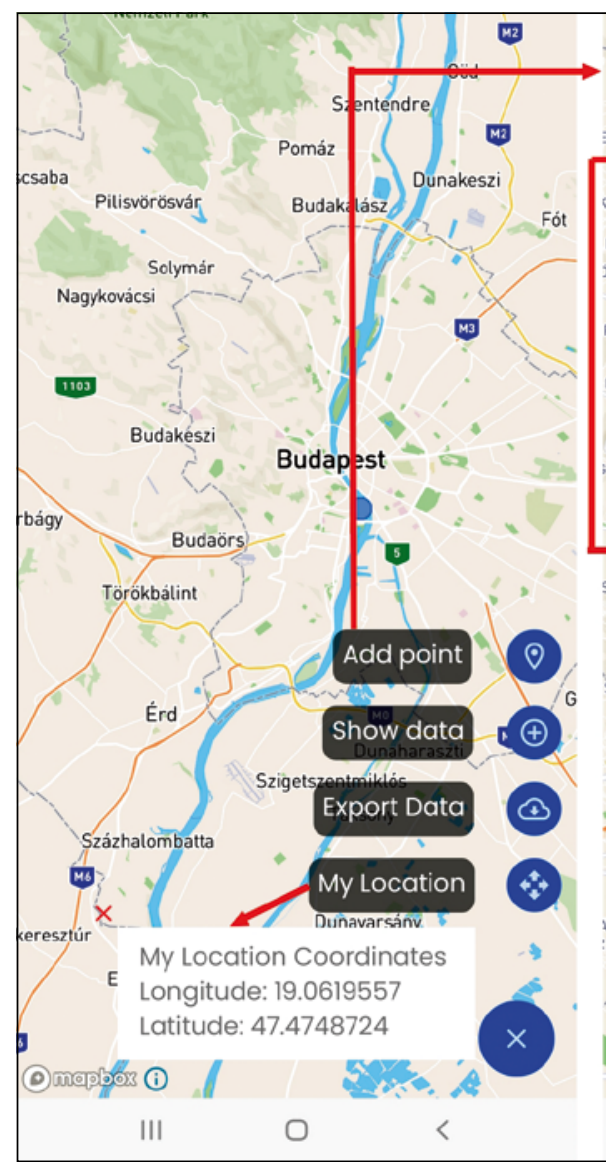

Fig. 4a. Toponyms App home interface

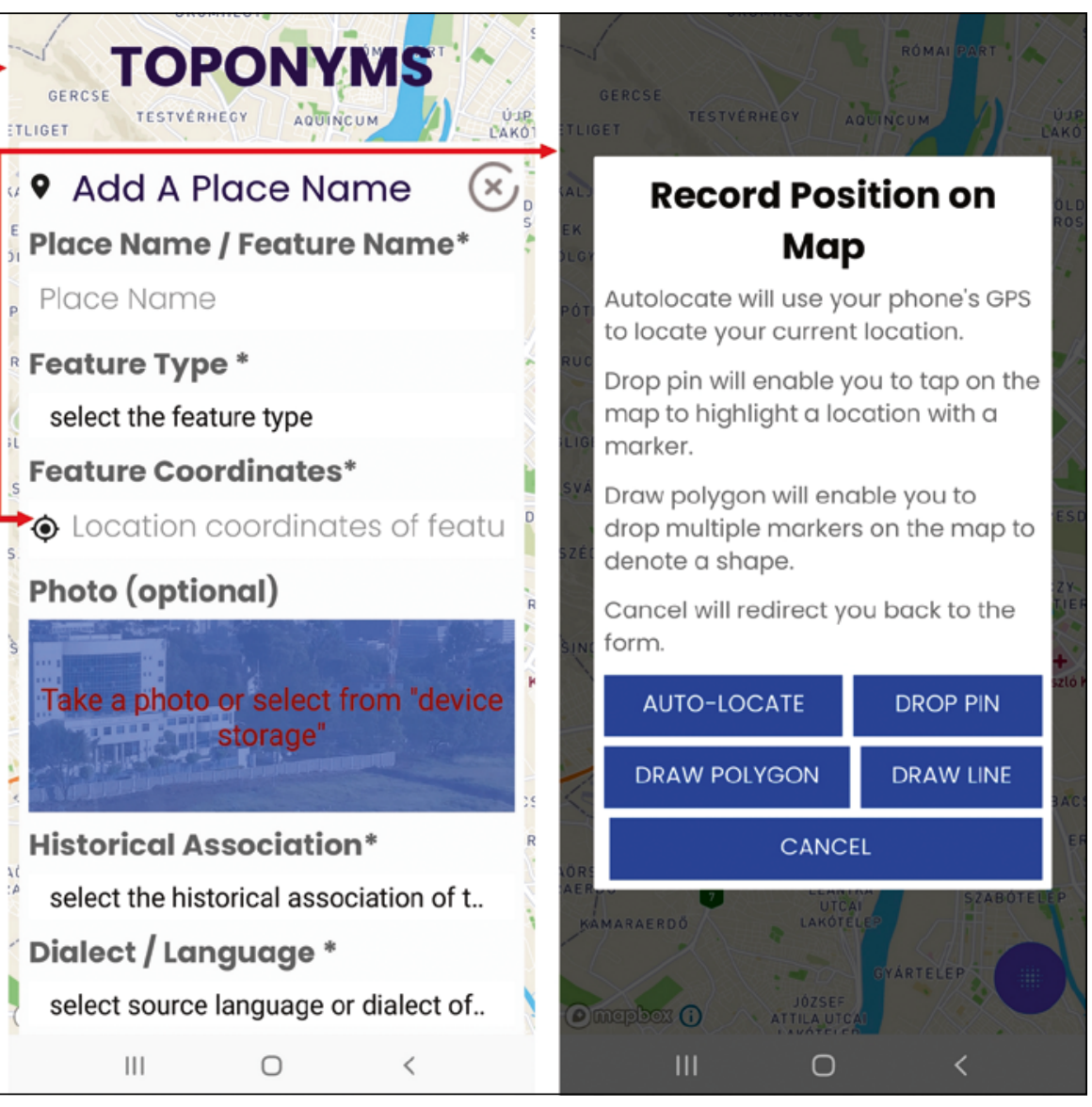

Fig. 4b. Adding a place name 
Digital Library (ADL), OSM, and GeoNames data classifications of feature types (Haklay 2010; Kostanski et al. 2012) and standards achieved were sufficient. However, we adopted feature types in GeoNames and OSM, with some compromise to visualize the various feature types adopted. There is no current prescribed highlevel classification applicable in a multilingual area with sparse and dense feature heterogeneity. Hence, any typology supported by features can suit. Our toponyms gazetteer can collect updates and verify all the gazetteer prototype records and with the potential to add more or new names in its database using the platforms provided. The limitation of the gazetteer configurations currently supports Kenya's dialects, editable at the administration site to suit any linguistic group after signing in to the PostgreSQL database. Besides, future work involves converting the GeoJSON data to RDF format since our database does not support RDF. We used GDAL/ OGR, a translator library that uses GeoJSON data format.

\section{References}

Acheson, E., Purves, R., \& DeSabbata, S. (2017). A quantitative analysis of global gazetteers: Patterns of coverage for common feature types. Computers, Environment and Urban Systems, 64. DOI: 10.1016/i.compenvurbsys.2017.03.007 Ballatore, A., Bertolotto, M., \& Wilson, D. (2012). Geographic Knowledge Extraction and Semantic Similarity in OpenStreetMap. 0-21.

Basiri, A., Jackson, M., Amirian, P., Pourabdollah, A., Sester, M., Winstanley, A., Moore, T., \& Zhang, L. (2016). Quality assessment of OpenStreetMap data using trajectory mining. Geo-Spatial Information Science, 19(1), 56-68. DOI: $10.1080 / 10095020.2016 .1151213$

Bensalem, I., \& Kholladi, M. K. (2010) Toponym disambiguation by arborescent relationships. Journal of Computer Science, 6(6), 653-659.

DOI: 10.3844 /jcssp.2010.653.659

Cardoso, S. D., Amanqui, F. K., Serique, K. J. A., Dos Santos, J. L. C., \& Moreira, D. A. (2015). SWI: A Semantic Web Interactive Gazetteer to support Linked Open Data. Future Generation Computer Systems, 54 , 389-398.

DOI: 10.1016/i.future.2015.05.006

Felgenhauer, T. (2018). Self-explanatory or just easy-to-use? A theoretical approach to the emancipatory potential of volunteered geographic information (VGI). GeoJournal, 83(4), 871-884.
DOI: $10.1007 / \mathrm{s} 10708-017-9794-7$

Haklay, M. (2010). How good is volunteered geographical information? A comparative study of OpenStreetMap and ordnance survey datasets. Environment and Planning B: Planning and Design, 37(4), 682-703. DOI: $10.1068 /$ b35097

Haklay, M., \& Weber, P. (2008). OpenStreet map: User-generated street maps. IEEE Pervasive Computing, 7(4), 12-18. DOI: $10.1109 /$ MPRV.2008.80

Hećimović, Ž., \& Ciceli, T. (2013). Spatial Intelligence and Toponyms. 26th International Cartographic Conference (ICC 2013). From Pole to Pole, August 2013, 1-13.

Hill, L. L. (2000). Core elements of digital gazetteers: Placenames, categories, and footprints. Lecture Notes in Computer Science (Including Subseries Lecture Notes in Artificial Intelligence and Lecture Notes in Bioinformatics), 1923, 280-290. DOI: $10.1007 / 3-540-45268-0 \quad 26$

Holovaty, A., \& Kaplan-Moss, J. (2008) The Definitive Guide to Django: Web Development Done Right. In S. Anglin, E. Buckingham, T. Campbell, G. Cornell, J. Gennick, J. Gilmore, K. Goff, J. Hassell, M. Moodie, J. Ottinger, J. Pepper, B. RenowClarke, D. Shakeshaft, M. Wade, \& T. Welsh (Eds.), Development (1st ed.). Apress. http://www.djangobook.com

Inkpen, D., Liu, J., Ghazi, D., Farzindar, A., \& Kazemi, F. (2017). Location detection and disambiguation from twitter messages. Journal of Intelligent Information Systems, 49(2). DOI: 10.1007/s10844-017-0458-3

Jia, J., Li, C., Zhang, X., Li, C., \& Carey, M. J. (2017). Towards Interactive Analytics and Visualization on One Billion Tweets. 28th Modern Artificial Intelligence and Cognitive Science Conference, MAICS 2017, 189-190. DOI: $10.1145 / 1235$

Keßler, C., Janowicz, K., \& Bishr, M. (2009). An agenda for the next generation gazetteer: Geographic information contribution and retrieval. In GIS: Proceedings of the ACM International Symposium on Advances in Geographic Information Systems (Issue c). DOI: $10.1145 / 1653771.1653787$

Klaus, S. (2020). Urban Activity Detection Using Geo-located Twitter Data Urban Activity Detection Using Geo-located Twitter Data Leveraging location-based data offers new perspectives on, and better understanding of, events. January. DOI: $10.1553 /$ giscience 2020

Knowles, A. K. (2018). Placing Names: Enriching and Integrating Gazetteers. The Journal of Interdisciplinary History, 48(4), 561-563. DOI: 10.1162/JINH_r 01212

Kostanski, L., Atkinson, R., Box, P., \& York, N. (2012). The Four Faces of Toponymic Gazetteers. Tenth United Nations Conference on the Standardization of Geographical Names, New York, 31 July - 9 August 2012, May, 1-9. https://unstats. un.org/unsd/geoinfo/ungegn/docs/10thuncsgn-docs/econf/E CONF.101 57 The $\% 20$ Four $\% 20 \mathrm{Faces} \% 20$ of $\% 20$ Toponymic\%20Gazetteers.pdf

Laurini, R. (2015). Geographic ontologies, gazetteers and multilingualism. Future Internet, 7(1), 1-23. DOI: $\underline{10.3390 / \mathrm{fi} 7010001}$

Machado, I. M. R. (2017). An ontological gazetteer and its application for place name disambiguation in text. Transactions in GIS, 21(4), 683-700.

DOI: $10.1111 /$ tgis. 12238

Machado, I. M. R., de Alencar, R. O., Campos, R de O., \& Davis, C. A. (2011). An ontological gazetteer and its application for place name disambiguation in text. Journal of the Brazilian Computer Society, 17(4), 267-279.

DOI: $10.1007 /$ s13173-011-0044-4

Meiring, B. (2008). Proudly South African: A toponymical excursion. Language Matters, 39(2), 280-299. DOI: $10.1080 / 10228190802579676$

Oliveira, M. G. de, Campelo, C. E. C., Baptista, C. de S., \& Bertolotto, M. (2016). Gazetteer enrichment for addressing urban areas a case study. Journal of Location Based Services, 10(2), 142-159. DOI: $10.1080 / 17489725.2016 .1196755$

Olteanu-Raimond, A. M., Hart, G., Foody, G. M., Touya, G., Kellenberger, T., \& Demetriou, D. (2017). The Scale of VGI in Map Production: A Perspective on European National Mapping Agencies. Transactions in GIS, 21(1), 74-90 DOI: $10.1111 /$ tgis.12189

Perdana, A. P., \& Ostermann, F. O. (2018). A citizen science approach for collecting toponyms. ISPRS International Journal of Geo-Information, 7(6). DOI: $10.3390 /$ ijgi 7060222

Rönneberg, M., Laakso, M., \& Sarjakoski, T. (2018). Map Gretel: social map service supporting a national mapping agency in data collection. Journal of Geographical Systems, 21(1), 43-59. DOI: $10.1007 / \mathrm{s} 10109-018-0288-\mathrm{z}$

Smart, P., Jones Christopher, \& Twaroch, F. (2011). Multi-Source Toponym Data Integration and Mediation for a MetaGazetteer Service. November. DOI: $\underline{10.1007 / 978-3-642-15300-6}$

Walravens, N. (2013). Validating a business model framework for smart city services: the case of fixmystreet. Proceedings - 27th International Conference on Advanced Information Networking and Applications Workshops, WAINA 2013, 1355-1360. DOI: 10.1109/WAINA.2013.11

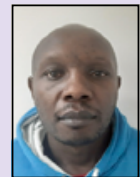

\section{Daniel Nyangweso PhD student}

Institute of Cartography and Geoinformatics, Eötvös Loránd University orongo@map.elte.hu

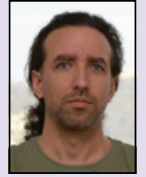

\section{Mátyás Gede \\ PhD \\ associate professor}

Institute of Cartography and Geoinformatics, Eötvös Loránd University saman@map.elte.hu 